\title{
Dialectics of Humanitarian Immigration and National Identity in Canadian Public Discourse
}

\author{
HARALD BAUDER
}

\begin{abstract}
Humanitarian immigration is an important element in the construction of Canada's identity as a liberal and compassionate country. Drawing on Hegelian dialectics, a discourse analysis of newspaper articles published between 1996 and 2001 examines processes of national identity formation through humanitarian immigration in the media. My interpretation of this discourse suggests that Canada's national identity is constructed on the basis of material inequalities through negation and sublation of refugees. By representing refugees who experience gender violence, children, and victims of natural disaster as deserving, the media construes an identity of Canada as compassionate. War criminals, supporters of hate crimes, and violent offenders are involved only to a limited degree in this dialectic.
\end{abstract}

\section{Résumé}

L'immigration à titre humanitaire est un élément important dans la construction de l'identité du Canada en tant que pays libéral et compatissant. Utilisant la dialectique hégélienne, une analyse de discours est entreprise d'articles de journaux publiés entre 1996 et 2001 afin d'examiner les processus de formation de l'identité nationale à travers l'immigration à titre humanitaire dans les médias. Mon interprétation de ce discours suggère que l'identité nationale du Canada est construite sur la base d'inégalités matérielles, à travers la négation et la 'réhabilitation' (l'anglais 'sublation', et l'allemand 'Aufhebung') de réfugiés. En présentant les réfugiés victimes de violences liées au genre, les enfants, et les victimes des ca- tastrophes naturelles comme méritants, les médias construisent une identité du Canada comme compatissante. Les criminels de guerre, les défenseurs des crimes de haine, et les contrevenants violents ne sont pris en compte que de façon limitée dans cette dialectique.

\section{Introduction}

Humanitarian immigration is, next to economic and family-oriented immigration, one of three pillars of Canadian immigration policy. Although refugees constituted only 13.6 per cent of all immigration to Canada in $2005,{ }^{1}$ the significance of this category lies in its ethical and political value. Through humanitarian immigration and refugee admission, Canada fulfills its commitment to humanitarianism and constructs a self-image as a liberal and compassionate nation. $^{2}$

In this paper I examine media discourse of humanitarian immigration. My analysis focuses on newspaper articles published in five major Canadian newspapers during a period when Canadian immigration reform was hotly debated in the press. Drawing on Hegelian ideas of dialectics, I interpret this discourse in the context of national identity formation. This interpretation highlights the press's representations of Canada's international reputation, discursive constructions of deserving vis-à-vis undeserving refugees, and coverage of contested cases of refugee applications and deportations.

In the next section, I review the literature on the dialectics of humanitarian immigration and national identity formation. Following a presentation of the research design, I present the results of my analysis. I end with a conclusion. 


\section{Dialectics of Humanitarian Immigration}

National identity is an important aspect of humanitarian immigration and the admission of refugees. In the context of Australia and Canada, Catherine Dauvergne observes: "Humanitarianism is about identity. The individual identity of the other who benefits from our grace is important, but only because of the light it reflects back on us." ${ }^{3} \mathrm{Her}$ argument, based on liberal political philosophy, suggests that humanitarianism serves as a way of defining "the nation as compassionate and caring." 4 Dauvergne's observation that "part of our humanitarianism is about ... applauding ourselves" 5 is echoed by Minelle Mahtani and Alison Mountz, whose discourse analysis of the newsprint media revealed that:

Clearly, Canadian immigration officials are looked upon favourably in the media when welcoming Kosovar refugees. We suggest that Canadians felt good about themselves vis-à-vis the press, the actions of government, and the contributions of citizens through that immigration event. ${ }^{6}$

Humanitarian immigration, however, can also contribute to the construction of an unfavourable identity of the receiving country. Mahtani and Mountz continue:

Months later, however, Canadian immigration officials came under attack for their treatment of the Chinese migrant boat crisis. The media scripted Canadians as irate citizens with a government constructed as "soft:" letting people in through the "back door."

Humanitarian immigration can serve the construction of a national self-image as positive or negative.

The manner in which this national identity is produced follows a dialectical process. In the context of humanitarian immigration, refugee selection policies and practices identify refugees as the Other, or the mirror image of the perceived national self. This process of identity formation relies on constructing and "reinforcing the boundary between an 'us' group and a 'them' group,"8 a process which relates to Georg W. F. Hegel's notion of "negation."

Following Ludwig Feuerbach, Karl Marx and Friedrich Engels rejected Hegel's emphasis on the internal reflection of the self-consciousness. Instead they suggested that the dialectical process has a material basis. ${ }^{10}$ This material basis is reflected in the process of national identity formation through humanitarian immigration. In contrast to liberal ideas of justice emphasizing principles of equality between human beings, "[h] umanitarianism is the opposite; it is grounded in a specific type of difference created by material inequality" 11 This material inequality defines who is a refu- gee and thus serves as an object of negation and national identity formation.

When four boats carrying 599 Chinese refugees arrived at Canada's western coast in 1999, the media represented these refugees as racialized, illegal, and non-belonging. These representations legitimated the rejection of the refugees and reaffirmed a European ethnic Canadian identity of Canada. ${ }^{12}$ The "regular" refugee selection process, however, serves a different role. It identifies the deserving Other, worthy of the nation's compassion. The nation exercises this compassion by granting refugee status. ${ }^{13}$

An additional element of the Hegelian dialectical movement is a second negation, or "sublation" (Aufhebung). ${ }^{14}$ With this second negation, the image of the Other is absorbed into the self. The admission of the foreigner and the "mysteries of strangeness" can be an important component in the replenishment of a nation. ${ }^{15}$ In the context of humanitarian immigration, the second negation consists of the inclusion of the refugee Other into the cultural identity of the national self. In Canada, " $[\mathrm{w}]$ hen refugees are admitted as permanent members of the community, they are literally invited to change their national identity;" 16 after three to four years of permanent residency they are encouraged to become Canadian citizens and embrace "Canadian" values and norms. ${ }^{17}$ The dialectical movement of othering and inclusion involves the resolution of the contradiction that refugees are "both other and not-other." 18 Refugees and humanitarian migrants "must be not like us in order to need our protection, but must be able to shed that identity and merge with the nation when required." 19

In the empirical part of this paper, I examine the media representation of refugees and humanitarian immigration to Canada. My aim is to examine the relationship between media reporting and the discursive construction of the national self.

\section{Research Design}

\section{Context}

In contrast to research examining the contents of refugee law and associated legal practices, ${ }^{20}$ I focus on the media discourse of humanitarian immigration during a period when the Canadian government reformed immigration law. During this period, humanitarianism was the second most frequently reported issue - behind "danger" and ahead of "political" and "economic-utility" issues of immigrationin the debate on immigration reform. ${ }^{21}$ Interestingly, the so-called war on terrorism coincided with an increase of media support for humanitarian immigration. ${ }^{22}$

The focus on the media debate of the reform of immigration law enables me to examine discursive processes in a context in which legal frameworks and material practices 
are rethought. ${ }^{23}$ In the analysis below, I explore the narratives through which the newsprint media constructs particular representations of refugees and humanitarian immigration. In the context of legal practice "national identity is the most powerful variable for giving an account of [immigration] law's features, changes, and applications." 24 The below analysis examines the role national identity plays in media discourse on immigration reform.

\section{Method}

I examined articles published in the Vancouver Sun, Calgary Herald, Toronto Star, National Post, ${ }^{25}$ and Ottawa Citizen between January 1, 1996, and December 31, 2004. This period coincided with the debate on immigration reform in Canada, which began with the release of the 1996 report Not Just Numbers: A Canadian Framework for Future Immigration by Canada's Immigration Legislative Review Advisory Group and included the passing of the Immigration and Refugee Protection Act in 2001. The search engine Canadian Newsstand enabled the electronic download of articles for the selected newspapers and study period. ${ }^{26}$ An initial search with the key words "immigration act" and "Canada" identified 490 articles. To select articles and text sequences dealing with the issue of humanitarianism I developed "recording instructions" for a priori coding of the data. ${ }^{27}$ The final sample contained 119 articles discussing humanitarian issues in the context of immigration reform.

Media debate is multidimensional and complex. ${ }^{28}$ The articles contained in the sample typically juxtaposed various opinions. Some commentaries, however, also presented singular viewpoints. For example, the National Post occasionally featured rather blatant commentaries by immigration critics Martin Collacott and Diane Francis. I examined these articles and commentaries for common themes and viewpoint in order to reconstruct distinct narratives associated with humanitarianism weaving through the media discourse of immigration. ${ }^{29}$

Such narratives typically represent elite interests. ${ }^{30}$ For example, the Immigration and Refugee Protection Act was passed by Parliament only two months after the September 11, 2001, attacks occurred in New York and Washington. In light of terrorism threats, the act allowed for "secret trials" and the indefinite detention and deportation of refugee applicants. In a press release in February 2002, Citizenship and Immigration Canada stated that the new Act is "tough for people who pose a threat to public security" and contains a "security agenda" apparently aimed at refugees and humanitarian immigrants. ${ }^{31}$ In the press, these interests of political elites in "national security" and solidarity with the United States are usually complemented and contested by viewpoints reflecting the interests of non-govern- mental organizations, community leaders, and other elite agents.

\section{Results}

\section{Canada's Reputation}

The newsprint media establishes the link between humanitarian immigration and national identity by making an association between immigration policy and Canada's reputation of compassion and tradition of generosity. In 1996, at the beginning of the debate on immigration reform, the Toronto Star quoted Citizenship and Immigration Minister Lucienne Robillard:

Canada has a tradition of fair and generous immigration and refugee programs," she said. "The [Immigration Legislative Review] advisory group will provide a series of recommendations to guide and update future immigration and refugee legislation in a way that will maintain this tradition. ${ }^{32}$

In 2001, when the Immigration and Refugee Protection Act was debated in Parliament, an article in the National Post paraphrased the chairman of the Commons Immigration Committee, Joe Fontana, who opposed the removal of rights from refugee applicants: "The bill must be tightened ... to protect Canada's reputation as a nation open to immigrants and refugees." ${ }^{33}$ While the government made adjustments to the Act before it took effect in June 2002, the Toronto Star opposed the denial of second hearings to rejected asylum seekers and accused Immigration Minister Denis Coderre of creating "A lopsided piece of legislation that compromises Canada's reputation as a safe haven for those whose lives are in danger at home." 34

The press often evokes Canada's reputation strategically to construct current policies and practices towards humanitarian immigration as problematic. For example, when the Canadian government proposed to stop recognizing Somali passports as legal identification, refugee advocates accused the government of racism and violating Canada's reputation as a champion of human rights. The Ottawa Citizen wrote:

"From the community perspective, this is a very racist piece of legislation and we think it's the way of curbing Somalis from coming into the country," said Hamdi Mohamed, program manager at the Somali Centre in Ottawa.

$\cdots$

To Ms. Mohamed, the situation "is disgusting, something that shouldn't be happening in a so-called civilized country that claims to advocate for human rights.."35 
Avvy Go, director of the Metro Toronto Chinese and Southeast Asian Legal Clinic, wrote an article in the Toronto Star using a similar strategy to advocate for better treatment of refugee claimants:

With the election now behind us, the first thing that our new minority government should do is to restore some compassion and basic respect for human dignity back into a system that has once made us all proud to be Canadians.

Then and only then, can we truly live up to our hard-earned reputation as one of the most humanitarian countries in the world. $^{36}$

The strategy of evoking Canada's international reputation is also used to construct arguments against humanitarian immigration and for toughening refugee policies. An article in the National Post proposes that the arrival of refugees from democracies, such as the United States, Israel, Hong Kong, and European countries, has made "refugee policy a la Canadien ... the joke of the globe" and "an embarrassment to Canadians." 37 An article in the Vancouver Sun presents the viewpoint of the Reform Party's immigration critic, Leon Benoit, that "all refugee claimants who arrive in Canada by illegal means should be detained and their cases decided within 30 days. It's the only way, he said, to get rid of Canada's reputation as a 'soft touch." 38 An editorial in the National Post presents the arrival of unwanted immigrants as a challenge to Canada's identity as a hospitable country: "By effectively encouraging economic migrants to enter our country illegally, the government only erodes our national sense of hospitality." 39

\section{Boundary Construction}

Regular refugee admission procedures are rarely discussed in the sample of newsprint articles. Apparently, conventional practices of refugee selection fail to make the news and do not contribute to the media's construction of Canada's identity. Rather, the representation of Canada as compassionate and caring occurs through reporting on borderline cases and contested refugee claims. These discussions construct the boundary of who is considered a "deserving" refugee.

A borderline area of humanitarian immigration relates to gender violence. An article in the Vancouver Sun featured a story on the court battle of a South Korean mother and her two daughters seeking refugee status on the grounds of domestic brutality:

Earlier that morning, the eldest child was vomiting at the prospect of being sent back to face a father who had threatened to kill them for running away, the family said.

Her mother had the look of the condemned.

Lawyer Jim Henshall argued that this woman and her daughters were being sent back to a society where spousal abuse and family violence were tolerated to a degree unknown in Canada, and that their family history of abuse-and belief that a vengeful husband and father was lying in wait-equated to a claim for refugee status. ${ }^{40}$

In another article, the Vancouver Sun defended the decision by the Immigration and Refugee Board to grant refugee status on the basis of gender violence to a Chinese woman who travelled on one of the boats that arrived at Canada's west coast in 1999.

She told the board she underwent a forced abortion 13 years ago, when she was seven months pregnant with her third child.

After the abortion, she told the board, she had another child in hiding. When authorities discovered she was pregnant with a fourth child, she was dragged to the hospital for another abortion, which included the fetus being injected with a poison in front of her. Later, she was forcibly sterilized.

The ruling includes an excerpt of the woman's interview with a psychologist in Canada about the second abortion.

"I thought she [the baby] was alive," the woman told the psychologist. "After it was aborted [the nurse] threw it in the corner on the floor. ... I told them: 'It is alive baby, let me have it, raise it.' They said: 'No, because of the injection it's going to die soon.' ... I saw her die and it was very painful. My heart got broken then."

"She cried shamelessly when describing her experiences," Robles wrote. "She was trembling and her hands were shaking as she testified." 41

Although the woman neither faces persecution in China nor fits the strict United Nations definition of a refugee, she received refugee status "because the 'atrocious and appalling' treatment she received in China before leaving ... caused her 'continuing psychological and emotional trauma." "42

In another case, the policy and program director of the Canadian Council for Refugees, Janet Dench, wrote a commentary in the Toronto Star on the government's proposal to establish a new Resettlement from Abroad Class (RAC) catering to people who are not refugees according the United Nations' definition but nevertheless in need of protection. Dench used the example of gender to illustrate the need for the proposed class: "the new class would mean an immigration official need not shut the door on an Afghan woman in a refugee camp in Pakistan simply because she is not singled out for persecution in her home country." ${ }^{43}$ By 
extending refugee status to cases of gender discrimination and violence, the Canadian media pushes the boundary of who is considered worthy of protection beyond international convention. In this way, the press affirms gender equality as a principle of Canadian identity and paints an image of Canada as compassionate towards women who suffer from the violation of this principle.

Another area of tension between the commitment to humanitarianism and current political practice involves children. The press sees vulnerable children as especially entitled to protection. When a federal court in Vancouver overturned the decision by the Immigration and Refugee Board (IRB) to deport nine Chinese refugee children an article in the National Post quoted the judge:

"The [children] were members of a 'particular social group,' [and this] warranted more serious consideration and analysis than was provided by the [IRB]," wrote Justice Frederick Gibson. "As members of a particular social group so defined, [their lawyers] urged that the children were persecuted by virtue of their being 'trafficked' on the basis of arrangements made between their parents and human smugglers ... I accept without reservation that argument." ${ }^{, 4}$

An article in the Toronto Star protests against Citizenship and Immigration Canada's intention to separate three refugee youths and suggested that "the conditions in which they were living violated their rights under the UN Convention on the Rights of a Child." ${ }^{45}$ The article highlighted why these youths are particularly deserving of compassion:

Last year, they say that Unita rebels attacked their hometown of Luanda, Angola's capital. Amid heavy gunfire, the girls say that they fled with their mother and neighbours. They say that the rebels captured them and blindfolded them so that they would not know the location of the camp where they were being taken. The last time the girls saw their mother, they say, was in the seconds before their blindfolds were put on. ${ }^{46}$

In another case, Canada's Supreme Court overturned the deportation order of a Jamaican refugee claimant to accommodate the needs of her four Canadian-born children. An article in the National Post celebrated the court's decision:

The court found that immigration officials were biased against [refugee claimant] Mavis Baker, and "completely dismissive" of the interests of her four Canadian-born children when they turned down her application to stay on humanitarian grounds.

"Children's rights and attention to their interests are central humanitarian and compassionate values in Canadian society," wrote Justice Claire L'Heureux-Dube in the unanimous decision. $^{47}$

Although this case involves the rights of children who are Canadian citizens, ${ }^{48}$ the text passage above illustrates the role of refugee policy and practice in constructing Canadian society as caring towards children and youths to remain with their parents.

A final example of a contested practice relates to victims of natural disaster. A Turkish-Canadian made an emotional plea to the Citizenship and Immigration Minister in the Ottawa Citizen to permit the sponsorship of a distant cousin who lost his right foot in an earthquake in Turkey but survived by lying in the rubble "on top of his father's body, unable to move for 35 hours. His foot was caught under the same block of cement as his father's, but thankfully he was not losing that much blood and he was able to survive. ... His only wish is to be able to come to Canada to at least escape from the horrible memories of the earthquake for a while." ${ }^{49}$ A reader's letter supported the admission of the earthquake victim and suggested that "under some circumstances, this law [Immigration Act of Canada] should be flexible." ${ }^{50}$ Both articles construct the earthquake victim as deserving due to the emotional and psychological hardship he experienced relative to the Chinese refugees who arrived around the same time via boat and whom the press portrayed as "illegal." 51

\section{Limits to Compassion}

National identity is constructed not only through the admission of refugees in need of protection, but also through the rejection of refugee applicants represented as unworthy of inclusion into Canadian society. For example, the press expresses little compassion for refugee applicants who committed war or hate crimes. An article in the Vancouver Sun supports efforts to deport war criminals from Latin America:

Some in Vancouver's Latino community call them los fantasmas de guerra - the ghosts of war.

The community applauds Canada's stepped-up efforts to expel the ghosts and deport those who have tortured and murdered civilians back home. ${ }^{52}$

Another example is the case of Ernst Zundel, who is wanted in his native Germany for hosting an anti-Semitic Web site that denies the Holocaust. An article in the $\mathrm{Na}$ tional Post reports that "Mr. Zundel's attempt to claim refugee status has caused outrage across Canada" 53 and another reiterates the Canadian government's position that "Holocaust denier Ernst Zundel is a threat to Canada's 
security because he fosters hatred of Jews, finances hate groups and could incite his followers to violence." 54

Violent criminals are also not wanted in Canada. An article in the National Post elaborates on the criminal history of Jose Salinas-Mendoza, an El Salvadorian refugee applicant, who "committed many crimes and was convicted of 12 offences ranging from drunken driving to sexual assault and assault." ${ }^{55}$ The article generalizes based on this case: "The only real refugees are those in camps, like the Kosovars, who cannot afford to get here in the first place. The rest are often tricksters, or worse." 56

Many articles share the general concerns that "criminals and queue jumpers are abusing our generosity" 57 and that "people are taking advantage of Canada's good will." 58 The term "bogus" refugee appears in articles throughout the study period. However, it was particularly frequent in the weeks before the Liberal government tabled the Immigration and Refugee Protection Act (Bill C-31) in April 2000. The Vancouver Sun expressed dissatisfaction with the proposed legislation for failing to "stop bogus claimants from clogging the system." 59 The National Post argued that "In Europe, nearly $90 \%$ of those claiming to be refugees are debunked as bogus" and that if "the West as a whole, and Canada in particular, is to provide a haven to genuine refugees, then we must satisfy ourselves that the refugees meet strict criteria." ${ }^{\prime 60}$ Drawing parallels to the Canadian refugee system, the Vancouver Sun featured an article on Britain, quoting British Conservative Party leader William Hague on the suffering by "genuine refugees ... because of the massive influx of bogus asylum seekers." 61 The term "bogus" represents a category of refugee applicants who are not only undesired but who also inflict damage by consum ing the resources needed to support "deserving" refugees.

\section{Contested Representations}

Although media discourse establishes boundaries separating "genuine" and "bogus" refugees, the allocation of refugee applicants to either side of the boundary is not always a straightforward choice. Sometimes, media opinions differ on whether an applicant is a "genuine" or "bogus" refugee. The former scenario entails that a refugees deserves protection; the latter implies the rejection of a refugee claim.

Throughout the study period, the press discussed the deportation of "terrorist" suspects to places where they could experience torture. ${ }^{62}$ Is Canada committed to protect all refugees from the prospect of torture? Or are "terrorist" suspects categorically undeserving of Canadian compassion and protection? The boundary between deserving fugitives of torture and undeserving "terrorists" itself is undisputed but the question is which category applies to a refugee applicant.
When the Supreme Court heard arguments in 2001 regarding the constitutionality of the anti-terrorist section of the Immigration and Refugee Protection Act, an article in the National Post reported that "a large number of intervenors, including the Canadian Bar Association, the Canadian Council for Refugees and the Canadian Civil Liberties Association, appeared before the court to argue that no one should be deported to possible torture." 63 Shortly after this article was published, another article in the National Post presented the other side of the argument:

[Several] court cases have made it clear [that terrorists] ... entered the country as refugee claimants. This was confirmed at the official level when the RCMP told a conference on Oct. 17 that the modus operandi of all international terrorists coming to Canada was first to claim refugee status and then move on to obtain welfare and medical benefits before turning to crime to boost their income. ${ }^{64}$

A case which occupied the newsrooms in 1999 involved Es-Sayy Jaballah, who is wanted in Egypt for inciting violence. An article in the Toronto Star illustrates the conflict between inadmissibility due to alleged involvement in "terrorism" and the protection of human rights:

He [Jaballah] came to Canada in 1996 and claimed refugee status. His claim was denied last March and he was arrested. He has been in custody since, and says he would be executed if he returned to his native Egypt.

-..

CSIS has accused Jaballah of maintaining contact with members of Egyptian al-Jihad, a group believed to be connected to last year's deadly embassy bombings in Kenya and Tanzania, court records show. ${ }^{65}$

Another case involved the Sri Lankan refugee Manickavasagam Suresh, an alleged fundraiser for the Liberation Tigers of Tamil Eelam (classified a "terrorist" organization in the United States), and the Iranian refugee Mansour Ahani, a former narcotics officer who was trained by the Iranian Ministry of Intelligence and Security in assassination techniques. Ahani's case was front-page material in 1999, when the National Post wrote:

The Canadian Security Intelligence Service believes that Mr. Ahani, whose appeal to stay was turned down recently in federal court, is a dangerous trained terrorist who works for a branch of Iran's government that plans and executes terrorist operations. Mr. Ahani's lawyers have fought his removal with a long series of challenges in the federal and Ontario courts. 
"We are now in a legal position to remove Mr. Ahani," said Huguette Shouldice, a spokeswoman for Citizenship and Immigration Canada. "We intend to remove him as expeditiously as possible. Canada won't be safe haven for terrorists or criminals." ${ }^{\prime 66}$

Two years later, in 2001, when the Supreme Court heard the cases of Suresh and Ahani, several newspaper articles reiterated the fear that Canada will become a "haven" for terrorists. ${ }^{67}$ An article in the Vancouver Sun elaborated on the treat of terrorism to Canada:

Terrorism and terrorist fund-raising are serious threats to Canada's security, particularly as this country is seen as a venue of opportunity for terrorists groups to raise funds, purchase arms and conduct other activities to support their organizations and terrorist activities elsewhere. ${ }^{68}$

An article in the National Post saw in Ahani and Suresh a challenge to freedom and democracy:

The Canadian Charter of Rights and Freedoms allows governments to subject individual rights to limits "justified in a free and democratic society."

"Nothing is more inimical to a free and democratic society than terrorism," the government will hope to convince the court. ${ }^{69}$

Text sequences that presented the counter-perspective typically allocated Suresh and Ahani's case to the side of the deserving fugitive of torture and highlighted Canada's international commitments to humanitarianism. For example, an article in the Ottawa Citizen argued:

Veteran [Supreme Court] Justice Frank Iacobucci led the pack with his assertion that sending people to countries where they would be tortured would "blow out of the water" international human rights conventions. ${ }^{70}$

Similarly, a report in the Toronto Star states: "Their [Ahani and Suresh's] lawyer Barbara Jackman says the principle in both cases is Canada's international reputation-'whether Canada is going to meet its commitment to the international community not to put people in a position where they may be tortured."'71

Another event that illustrates the contested representations of refugees either as unwanted criminals or victims of human rights abuses involved the deportation of six Somalis from Canada to Mogadishu. An article in the $\mathrm{Na}$ tional Post defended the protection of human rights by appealing to "Canadian values and principles" of humanitarianism:

Some of the deportees had never been to Mogadishu before; many had been raised in North America and were unfamiliar with their native country.

Under the watch of 15 private security officers, the group was flown to Somalia and left in Mogadishu, which many consider to be the world's most dangerous city ...

"We are extremely concerned for these people," says Mahamoud Hagi-Aden, a Somali-Canadian and a consultant to the Somali Centre for Family Services, based in Ottawa.

$\cdots$

Mr. Hagi-Aden suggested that the joint removal was undertaken covertly, in order not to attract attention. "We work very closely with Immigration Canada, and are usually informed about deportations. In this case, we didn't hear anything. I think it runs contrary to Canadian values and principles." 72

The media debate of these cases illustrates arising contradictions when people are pigeonholed into categories of deserving and undeserving refugees.

\section{Complexity of Media Narratives}

The complexity of media discourse is further demonstrated by voices that complicate the narratives that I presented above. For example, newsprint reporting occasionally highlighted aspects to the humanitarian international reputation of Canada beyond the binary representation of Canada as neither compassionate nor "soft." An article in the Ottawa Citizen quoted Tom Clark, coordinator of the Interchurch Committee for Refugees, who "suspects Canada is currently 'the deportation capital of the world."'73 Another article in the Toronto Star implies that the number of refugees entering Canada is too small to warrant constructions of Canada as either compassionate or soft on the basis of humanitarian immigration:

In fact, those presenting their claims for Convention refugee status at Canada's door numbered only 21,803 last year. Out of more than 30 million refugees worldwide, not counting some 15 million "internally displaced," a minuscule 0.0007 per cent arrive here as claimants. ${ }^{74}$

Another example of a challenge to the narratives identified above is the suggestion that Canada's refugee selection process is not guided by humanitarian principles but rather by self-interest. The same article points out that Canada receives mostly the young, motivated, and affluent: "And it's 
not the 'masses' who make it to Canada ... Here, you don't see many old people. Only the well-to-do or the very inventive and very courageous." 75 Another article in the Toronto Star criticizes Canada's pick-and-choose attitude in respect to refugee selection:

There is a deep-rooted prejudice against refugees who present themselves in Canada and ask for asylum. ... They are viewed as an inconvenience because, by virtue of their presence, we are legally obliged to respect their human rights.

When refugees are overseas, on the other hand, we can pick and choose where and how and when we will bestow our generosity. $^{76}$

These examples illustrate that the narratives contained in the newsprint media's reporting on humanitarian immigration are not uncontested. In fact, many reporters and commentators seek to destabilize conventional media perspectives.

\section{Conclusion}

Many newspaper articles I examined suggest that Canadian humanitarian immigration policies and the practices of refugees admission are important positive aspects of the image other countries have of Canada. The light this international reputation reflects back on Canada creates an identity of compassion. This interpretation of the media discourse of humanitarian immigration corresponds with existing research on the relationship between humanitarian immigration and national identity. ${ }^{77} \mathrm{My}$ analysis further suggests that journalists and commentators strategically juxtapose Canada's reputation with current political and administrative practices to construe some policies and practices as problematic-either as falling short of or overshooting Canada's identity as a country of compassion and champion of human rights.

Media discourse negates Canadian national self-identity by discussing the circumstances that deserving refugees are enduring. These circumstances are presented as unacceptable to Canada, requiring Canada to provide protection from them. In this context, media reporting focuses on disputed refugee claims and contested humanitarian policies. In particular, the representation of women who experience discrimination and violence, children who are separated from or abused by their families, and victims of natural disaster as deserving refugees creates an image of Canada as a gender-equal society which protects children and supports victims of disaster. In these newsprint discussions, violence, abuse, and misfortune constitute the material conditions for the negation of the national self.
The integration of refugees into Canadian national identity, i.e. the second negation, was rarely addressed in the sampled articles. If it was discussed at all, it was mostly implied. For example, in an article in the National Post, the expectation that refugees from wartorn Kosovo become permanent residents and eventually Canadian citizens became apparent only when Canada's refugee policy was compared with that of "the U.S. [which] is insisting that all 20,000 Kosovars who it is giving temporary sanctuary must be returned to Kosovo when peace is restored,"78 and when the article quoted Foreign Affairs Minister Lloyd Axworthy's defence of Canada's practice as "part of our refugee commitments." 79

The newspaper articles also established the limits of Canada's compassion. The press was outraged when war criminals, supporters of hate crimes, and violent offenders sought refuge in Canada. Obviously, the press does not sanction such behaviour and denies these refugee applicants compassion. The ideologies they embody have no place in Canadian society. The newsprint media does not represent these applicants as "both other and not-other." 80 Their representations constitute a negation of the national self, but the second negation-their absorption into the Canadian national community-is prevented. They are excluded from the dialectic of humanitarian immigration beyond the first negation. Interestingly, unlike deserving refugees who are represented as passive victims, undeserving refugees are portrayed as active agents of violence, crime, and immorality. Furthermore, what define refugees as undeserving are not material conditions of inequality but violations of ideological taboos.

The discursive boundary drawing between the circumstances that define deserving and undeserving refugees is a separate process from allocating individuals to either side of this boundary. Noteworthy media debates involved the cases of refugees who are accused of supporting terrorism but who could be tortured if deported. As terrorism supporters they are unworthy of incorporation into Canadian society, but as victims of torture they deserve compassion. The media debates of these cases illustrate that the question of admissibility is not a matter of degree of worthiness on a scale of material inequality, but rather a contradiction between conditions of material inequality and ideological incompatibility. This contradiction, however, has not been resolved-either in media discourse or at the level of policy and law in which this discourse is embedded.

\section{Notes}

1. An additional 2.5 percent of "humanitarian and compassionate cases" were classified "other immigrants"; see Citizenship 
and Immigration Canada, "Canada - Permanent Residents by Category," Facts and Figures 2005, <http://www.cic.gc.ca/english/pub/facts2005/overview/03.html> (accessed March 31, 2007).

2. Catherine Dauvergne, Humanitarianism, Identity, and Nation: Migration Laws of Australia and Canada (Vancouver: University of British Columbia Press, 2005).

3. Ibid., 164.

4. Ibid., 75 .

5. Ibid., 73.

6. Minelle Mahtani and Alison Mountz, "Immigration to British Columbia: Media Representations and Public Opinion," Research on Immigration and Integration in the Metropolis Working Paper Series No. 02-15 (Metropolis BC: 2002): 29.

7. Ibid.

8. Ibid., 72 .

9. Georg W. F. Hegel, Phänomenologie des Geistes (Paderborn: Voltmedia, 2005 [1807]).

10. Karl Marx and Friedrich Engels, Die deutsche Ideologie (Berlin: Dietz Verlag, 1953).

11. Dauvergne, 72 .

12. Sean P. Hier and Joshua L. Greenberg, "Constructing a Discursive Crisis: Risk, Problematization and Illegal Chinese in Canada, Ethnic and Racial Studies 25, no. 3 (2002): 490-513.

13. Dauvergne.

14. Hegel.

15. Bonnie Honig, Democracy and the Foreigner (Princeton, NJ: Princeton University Press, 2001), 4.

16. Dauvergne, 124.

17. The Canadian citizenship test and the booklet A Look at Canada explicitly request those becoming Canadians to endorse the "democratic values" of "equality," "respect for cultural differences," "freedom," "peace," and "law and order," and define "multiculturalism," "volunteerism," and "protecting the environment" as Canadian values; Citizenship and Immigration Canada, Ottawa, <http://www.cic.gc.ca/english/look/look-00e.html> (accessed March 28, 2007).

18. Dauvergne, 162.

19. Ibid.

20. E.g. Dauvergne.

21. Harald Bauder, "Immigration Debate in Canada: How Newspapers Reported, 1996-2004," Journal of International Migration and Integration, forthcoming.

22. Ibid.

23. I assume here that public discourse of immigration shapes and is shaped by social conventions, legal practices, and immigration law; see Tuen van Dijk, Communicating Racism. Ethnic Prejudice in Thought and Talk (Newbury Park: Sage, 1987); Tuen van Dijk, Racism and the Press (London: Routledge, 1991); I. Crespi, The Public Opinion Process: How the People Speak (London: Lawrence Erlbaum Associates Publishers, 1997). However, this relationship is complex and media opinion on immigration does not always translate into immigration policy and law; Bauder.

24. Dauvergne, 26.
25. Although the National Post was called Financial Post until 1998, I only use the name National Post in the text.

26. The records of the Globe and Mail were incomplete. I did not include this newspaper in the sample.

27. S. Stemler, "An Overview of Content Analysis," Practical Assessment, Research and Evaluation 7, no. 17 (2001), $<$ http://pareonline.net> (accessed December 2006).

28. Crespi; Norman Fairclough, Discourse and Social Change (Cambridge: Polity Press, 1992); Minelle Mahtani, "Representing Minorities: Canadian Media and Minority Identities," Canadian Ethnic Studies 33, no. 3 (2001): 99-133; M. Wetherell, S. Taylor, and S. J. Yates, eds. Discourse as Data: A Guide to Analysis (London: Sage, 2001).

29. Fairclough.

30. Van Dijk, Communicating Racism; van Dijk, Racism and the Press. In addition to elite interests represented in media discourse, the ownership of newspapers affects reporting, as exemplified by the Calgary Herald, Vancouver Sun, and National Post sometimes publishing identical articles. Reprinted articles were not double-counted in the sample.

31. Citizenship and Immigration Canada, Fair and Equitable Response From Minister, News Release 2002-01, Ottawa, $<$ http://www.cic.gc.ca/english/press/02/0201-pre.html> (accessed September 2006).

32. David Vienneau, "Ottawa to 'Update' Immigration Act to Be Modernized for $21^{\text {st }}$ Century, Minister Says," Toronto Star, November 26, 1996, A2.

33. Robert Fife, "Liberals Spar Over Changes to Immigration Act," National Post, March 19, 2001, A7.

34. Toronto Star, "Wrong Balance," May 1, 2002, A20.

35. Jennifer Pritchett, "Somali Community Outraged by 'Racist' Legislation," Ottawa Citizen, August 10, 1999, B3.

36. Avvy Go, "Refugee System Lacks Compassion," Toronto Star, July 20, 2004, A18.

37. Diane Francis, "Refugee System Needs Total Overhaul," National Post, April 22, 1999, C3.

38. Andres Duffy, "UN Envoy Urges Canada to Remain Open to Refugees," Vancouver Sun, February 2, 2000, A6.

39. National Post, "Human Cargo," April 3, 2000, A17.

40. Gerry Ballett, "Helping People to Stay Here," Vancouver Sun, July 22, 2004, B2.

41. Chad Skelton, "Woman Gets Refugee Status despite No Fear of Persecution," Vancouver Sun, June 2, 2000, A4.

42. Ibid.

43. Janet Dench, "Refugee Policy Contradicts Itself," Toronto Star, January 20, 1997, A13.

44. Finbarr O’Reilly, "Chinese Migrant Children Spared Deportation," National Post, December 21, 2000, A4.

45. Carol Lower, "Searching for a Home," Toronto Star, October 28, 2001, A6.

46. Ibid.

47. Marina Jimenez, "Children's Fate Key in Deportation Cases," National Post, July 10, 1999, A8.

48. The case of Ms. Baker and her children is not unique and the press reported on numerous similar cases. For example, the 
Toronto Star supported a court decision in favour of a single mother and refugee claimant whose two Canadian-born children were scheduled for deportation; see "Another Half-baked Idea from Lucienne Robillard," Toronto Star, May 12, 1998, 1. An article in the Calgary Herald criticized the lack of compassion in a decision by Citizenship and Immigration Canada to deport a Sri Lankan refugee although her husband and two children posses Canadian citizenship; Andy Marshall, "Calgary Family Fears Mom May be Deported," Calgary Herald, February 19, 1999, B8). An article in the National Post laments that "family unity is often disregarded, particularly in deportation cases"; Francisco Martinez, "Canada Is a Human Rights Violator," National Post, April 5, 1999, A14)

49. Berna Avunca, "Turkish-Canadians Can't Rescue Destitute Relative," Ottawa Citizen, September 18, 1999, B5.

50. Gurel Karaokcu, "Turkish-Canadians Should Be Able to Rescue Relatives," Ottawa Citizen, September 25, 1999, B5.

51. Hier and Greenberg.

52. Richard Ouston and Marina Jimenez, "Latinos Still Haunted by Ghosts of War," Vancouver Sun, February 23, 1998. Although the article presents the counter-argument that war crimes were often committed by coerced peasants, the authors express their opinion by ending with a quote from a spokesperson of the Centre for Latin American Vancouverites Ethnic Society: "No-one has the right to torture another human being, even if you're involved in a civil war. Everyone has a choice."

53. Bill Curry and Stewart Bell, "Germany Wants Zundel Extradited," National Post, February 21, 2003, A4.

54. Stewart Bell, "Zundel Ordered Held as a National Security Risk," National Post, March 1, 2003, A4.

55. Diane Francis, "Refugee System Needs Total Overhaul: Criminals Allowed In at Expense of Real Victims," National Post, April 22, 1999, C3.

56. Ibid.

57. Toronto Star, "Immigration Reforms Strike Right Balance," April 9, 2000, 1.

58. Barbara Yaffe, "Immigration Act Has Been a Disaster for Canada," Calgary Herald, May 25, 2000, A22. This article was also published in the Vancouver Sun, May 24, 2000, A15.

59. Vancouver Sun, "Ottawa Is Missing the Boat on Refugees," March 20, 2000, A8.

60. National Post, "Human Cargo," April 3, 2000, A17.

61. Kevin Ward, "Britain's Refugee Debate Offends UN Agency," Vancouver Sun, April 14, 2000, A14.

62. For example: Alan Borovoy, "Deportation Rules Test Canada's Sense of Fairness," Toronto Star, January 1, 1996, A 11; Jim Bronskill, "Lawyer Fears for Woman's Life," Ottawa Citizen, March 19, 1997, A1; Allan Thompson, "Immigration Bill Called 'Un-Canadian," Toronto Star, March 16, 2001, A6.

63. Luiza Chwialkowska, "Terrorist Deportation Policy Can Withstand Challenge, McLellan Says," National Post, October 3, 2001, A10.
64. Martin Collacott, "Political Will Needed to Guard the Border," National Post, October 22, 2001, A10.

65. Donovan Vincent, "Refugee Claimant Accused of Lying." Toronto Star, August 26, 1999, A1.

66. Marina Jimenez, "Officials Ready to Deport Suspected Iranian Assassin,” National Post, July 8, 1999, A1.

67. Stewart Bell, “Court Ruling Could Make Canada 'Haven' for Terrorists, Assassins," National Post, February 17, 2001, A1; Luiza Chwialkowska, "Refugees' Case Has Developed into Slowdown of Ideologies," National Post, May 21, 2001, A8; Janice Tibbetts, "High Court to Decide if Suspected Terrorist Can Stay," Vancouver Sun, May 22, 2001, A3; Janice Tibbetts, “Top Court Pleas for Refugee Terrorists," Ottawa Citizen, May 23, 2001, A5 (also published in Calgary Herald); Janice Tibbetts, "Justice May Be Asked to Rehear Case of Tamil, Iranian," National Post, September 20, 2001, A8 (also published in Ottawa Citizen).

68. Janice Tibbetts, "High Court to Decide if Suspected Terrorist Can Stay," Vancouver Sun, May 22, 2001, A3.

69. Luiza Chwialkowska, "Refugees' Case Has Developed into Slowdown of Ideologies," National Post, May 21, 2001, A8.

70. Janice Tibbetts, "Top Court Pleas for Refugee Terrorists," Ottawa Citizen, May 23, 2001, A5 (also published in Calgary Herald).

71. Tonda MacCharles, "Terror Suspects to Learn Fate Today," Toronto Star, January 11, 2002, 7.

72. Brian Hutchinson, "Canadian Deportees Dumped in War Zone," National Post, March 9, 2002, A1.

73. Bob Harvey, "Church Leaders Demand Better Treatment for Refugees," Ottawa Citizen, April 4, 1997, A4.

74. Susan Kastner, "Strangers in a Strange Land," Toronto Star, May 31, 1997, L1.

75. Ibid., quoting social activist and recipient of the Order of Canada, Mary Jo Leddy.

76. Janet Dench, "Refugee Policy Contradicts Itself," Toronto Star, January 20, 1997, A13.

77. Dauvergne, supra; Mahtani and Mountz, supra.

78. Robert Fife, "Airlift of Refugees Causing a Rift in NATO Alliance," National Post, April 7, 1999, A12.

79. Ibid.

80. Dauvergne, 162.

Harald Bauder is an associate professor in the Geography Department at the University of Guelph, Ontario. His research interests involve immigration discourses and labour market inclusion of immigrants in Canada and Europe. He recently published the book Labor Movement: How Migration Regulates Labor Markets (New York: Oxford University Press, 2006). 